\title{
THE BLOOD PLATELETS IN HEMOPHILIA *
}

\author{
GEORGE R. MINOT, M.D., AND ROGER I. LEE, M.D. \\ BOSTON
}

Hemophilia on account of its striking nature was early recognized as a clinical entity, and has been the subject of many observations. Many theories as to its causation have been advanced. With the development of methods for the study of the blood it has been possible to discard most of the theories concerning this interesting disease.

It has been conclusively shown that in typical cases the numerical counts of the formed elements of the blood, the erythrocytes and the leukocytes are within normal limits. The blood platelets may be somewhat increased. It has also been shown in typical cases that certain active principles of the blood that participate in clotting occur in normal amounts. The hemophilic blood serum ${ }^{1}$ contains the normal amount of thrombin, the active coagulating principle, and this thrombin behaves in an entirely normal fashion. It has further been shown that the hemophilic blood clot, when once formed, is as tough and firm as normal and retracts in normal fashion. The fibrinogen ${ }^{2}$ and calcium ${ }^{3}$ are considered to be within normal limits.

It has been suggested that the presence of an excess of some anticoagulating substance was the cause for the long coagulation time exhibited by hemophilic blood. Weil ${ }^{4}$ has given some experimental evidence that an excess of antithrombin occurs in hemophilic blooci. Howell, ${ }^{5}$ however, was not able to find that his antithrombin was notably increased in hemophilia. The findings of Hurwitz and Lucas, ${ }^{6}$ Hess $^{7}$ and our studies confirm Howell's findings in regard to antithrounbiri.

\footnotetext{
* Submitted for publication June 5, 1916.

* From the Pathological Laboratory, J. H. Wright, director, and the Medical Service of the Massachusetts General Hospital.

1. Fonio: Mitt. a. d. Grenzgeb. d. Med. u. Chir., 1914, xxviii, 313. Addis: Jour. Path. and Bacteriol., 1911, xv, 427. Gressot: Zeschr. f. klin. Med., 1912, 1xxvi, 194. Morowitz and Lossen: Deutsch. Arch. f. klin. Med., 1908, xciv, 110.

2. Addis: Jour. Path. and Bacteriol., 1911, xv, 427. Sahli: Ztschr. f. klin. Med., 1905, lvi, 264 ; Deutsch. Arch. f. klin. Med., 1910, xcix, 518. Hurwitz and Lucas: The Archives Int. Med., 1916, xvii, 543.

3. Addis: Jour. Path. and Bacteriol., 1911, xv, 427. Nolf: Ergebn. d. inn. Med. u. Kinderh., 1913, x, 275. Morowitz and Lossen: Deutsch. Arch. f. klin. Med., 1908, xciv, 110. Hess: Bull. Johns Hopkins Hosp., 1915, xxvi, 372.

4. Weil: Bull. et mém. Soc. méd. hôp. de Paris, 1906; Presse méd., 1905, xiii, 673.

5. Howell: The Archives INt. Med., 1914, xiii, 76.

6. Hurwitz and Lucas: Footnote, 2, last reference.

7. Hess: The Archives Int. Med., 1916, xvii, 203.
} 
Morawitz and Lossen $^{8}$ and $\mathrm{Sahli}^{9}$ are inclined to attribute the faulty coagulation to an insufficiency or defective formation of the element known in various terminologies as thrombokinase, thromboplastic substance, ${ }^{10}$ tissue juice, cytozyme or thrombozyme. This is similar to the view of Nolf and Herry, ${ }^{12}$ who believe that there is a quantitative or qualitative deficiency in the thrombozyme, which occurs in the blood platelets in the circulating blood in contrast to the similar factor in the tissues. These various substances mentioned above are not exactly identical in the various terminologies, but can be considered roughly comparable and are found in the blood platelets and tissue juices. The action ascribed to them varies according to the theories of coagulation; all theories hold in common that they accelerate the coagulation of the blood.

Addis $^{13}$ believes that the abnormality of hemophilic blood is to be found in the property of the prothrombin, that it is altered in character so that it requires a longer time than normal for its activation to thrombin. Howell ${ }^{5}$ concludes from his experiments that it is the actual amount of prothrombin that is altered in the hemophilic blood and is inclined to believe that it is the deficiency in the amount of prothrombin with the resulting relative excess of antithrombin that is responsible for the abnormally long coagulation time. He does not deny to the blood platelets a share in this deficiency.

The action of blood platelets from cases of hemophilia has received but little study and forms the basis of this paper.

Fonio, ${ }^{14}$ who believes that the active coagulating principle in the tissues, while similar, is not identical with that of the blood platelets, is inclined to attribute the delayed coagulation in hemophilia, from the study of one case, to an insufficiency of thrombozyme or blood platelets, which are present in sufficient amounts. Sahli ${ }^{15}$ in 1910 demonstrated similar differences with hemophilic and normal red blood cells as Fonio did with platelets. His results, perhaps, were due to platelets contained in his red cell suspensions. Addis ${ }^{18}$ has discussed Sahli's results.

The experiments given below were made with the blood platelets obtained from two typical cases of hemophilia and show clearly that hemophilic platelets do not act like normal platelets. The platelets of a third case of hemophilia, a mild case, gave the same, but less striking, results.

8. Morawitz and Lossen: Footnote 1, last reference.

9. Sahli : Footnote 2, second reference.

10. Howell: Am. Jour. Physiol., 1912-1913, xxxi, 1.

12. Nolf and Herry: Rev. de méd., 1909, xxix, 841; 1910, xxx, 20 and 106.

13. Addis: Footnote 1, second reference.

14. Fonio: Cor.-Bl. f. schweiz. Aerzte, 1915, xlv, 1505; Footnote 1, first reference.

15. Sahli : Footnote 2, second reference. 
METHODS

Plasma was obtained from the hemophilic blood without adding any oxalate or other foreign substance, by drawing the blood from the arm vein into a paraffined syringe and centrifugalizing it, by preference, in iced paraffined tubes. A clear plasma containing very few platelets could easily be obtained, which did not clot for twelve hours. The cloudier the plasma, that is, the more platelets it contained, the quicker it clotted. Platelet suspensions in normal salt solution were obtained from the "buffy coat" and from the cloudy plasma of the hemophilic blood by the usual technic described first by Mosen ${ }^{16}$ and later modified by us. ${ }^{17}$ Platelets were obtained also from the cloudy plasma and "buffy coat" of oxalated, citrated, and magnesium sulphate normal and hemophilic plasmas. The results with the hemophilic platelets were essentially the same irrespective of the particular method of obtaining them or the number of washings. The same was true of the normal platelets.

\section{ACTION OF PLATELETS ON HEMOPHILIC PLASMA}

The effect of adding suspensions of hemophilic and normal platelets to hemophilic plasma is shown in Tables 1,2 and 3.

Hemophilic plasma clots most rapidly on the addition of normal platelets. Roughly, the time varies inversely to the number of platelets. Yet an increase of platelets above a certain amount, relatively small, does not greatly shorten the time. Hemophilic platelets hasten somewhat the clotting of hemophilic plasma, although nowhere nearly as markedly as normal platelets in the same concentration. In each instance the clotting time of the mixture of hemophilic plasma and hemophilic platelets in any concentration of platelets is always markedly longer than the clotting time of the mixture of hemophilic plasma and normal platelets. Even when the mixture contains seventyfive times as many hemophilic platelets as ordinarily occur in the circulating blood, the clotting time of the mixture is abnormal and markedly longer than the clotting time of a mixture of hemophilic plasma and normal platelets in which the platelets are approximately in the same number as in the circulating blood. The same results were obtained whether the platelets from one hemophilic case were added to its own or to another hemophilic plasma. The platelets obtained from the hemophilic case with the longest coagulation time usually, but not always, required a somewhat longer time to cause a hemophilic plasma to clot than those from the case with the shorter coagulation time. An example of this is given in Table 3 . These studies were repeated many times.

16. Mosen: Arch. f. Anat. u. Physiol., 1893, Physiol. Abst., p. 352.

17. Lee and Vincent: The ARChives INt. MED., 1914, xiii, 398. 
TABle 1.-Erfect of Adding Hemophilic and Normal Platelets to Hemophilic Plasma

\begin{tabular}{|c|c|c|c|}
\hline $\begin{array}{l}\text { Strength of Platelet } \\
\text { Suspension }\end{array}$ & $\begin{array}{l}\text { Variety and Amount of } \\
\text { Platelet Suspension } \\
\text { Added to } 6 \text { Gtt. of } \\
\text { Hemophilic Plasma }\end{array}$ & \begin{tabular}{|c|} 
Time \\
Coagulation \\
Begins, \\
Minutes
\end{tabular} & $\begin{array}{l}\text { Time for } \\
\text { Solid Clot } \\
\text { to Form, } \\
\text { Minutes }\end{array}$ \\
\hline \multirow{4}{*}{ Saturated.. } & Normai 2 gtt.......... & 4 & 6 \\
\hline & Normal 3 gtt. ........ & 4 & 5 \\
\hline & Hemophilic $2 \mathrm{gtt} . .$. & 21 & 42 \\
\hline & Hemophilie 6 gtt. ... & 13 & 23 \\
\hline \multirow{4}{*}{$\begin{array}{l}\text { Flatelets about four times as concen } \\
\text { trated as in blood........................ }\end{array}$} & Normal $2 \mathrm{gtt} . . . .$. & 5 & 8 \\
\hline & 'Normal 3 gtt. ....... & 5 & 7 \\
\hline & Hemophilic 2 gtt. ... & 38 & 55 \\
\hline & Hemophilic 6 gtt. .... & 38 & 55 \\
\hline
\end{tabular}

TABLE 2.-Effect of Adding Hemophilic and Normal Platelets to Hemophilic Plasma

\begin{tabular}{|c|c|c|c|}
\hline $\begin{array}{l}\text { Strength of Platelet } \\
\text { Suspension }\end{array}$ & $\begin{array}{l}\text { Variety and Amount of } \\
\text { Platelet Suspension } \\
\text { Added to } 6 \text { Gtt. of } \\
\text { Hemophilic Plasma }\end{array}$ & \begin{tabular}{|c|} 
Time \\
Coagulation \\
Begins, \\
Minutes
\end{tabular} & $\begin{array}{l}\text { Time for } \\
\text { Solid Clot } \\
\text { to Form, } \\
\text { Minutes }\end{array}$ \\
\hline \multirow{2}{*}{ About twice as concentrated as in blood } & Normal $3 \mathrm{gtt} . . . . .$. & 19 & 24 \\
\hline & Hemophilic 3 gtt. & 77 & 120 \\
\hline \multirow{3}{*}{ 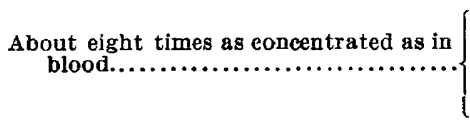 } & Normal $2 \mathrm{gtt} . \ldots \ldots$ & 18 & 22 \\
\hline & Hemophilic $2 \mathrm{gtt}$. & 55 & 95 \\
\hline & Hemophilic Il gtt. .. & 52 & 85 \\
\hline \multirow{2}{*}{$\begin{array}{l}\text { About sixteen times as concentrated as } \\
\text { in blood....................................... }\end{array}$} & Normal 2 gtt. ..... & 16 & 21 \\
\hline & Hemophilic 2 gtt... & 47 & 72 \\
\hline \multirow{3}{*}{ 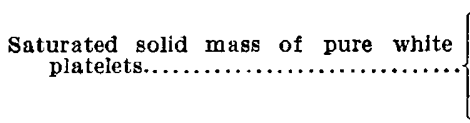 } & Normal $2 \mathrm{gtt} . . . . . .$. & 15 & 20 \\
\hline & Hemophilic $2 \mathrm{gtt} . . . . . .$. & 50 & 76 \\
\hline & Hemophilic $10 \mathrm{gtt}$. . & 35 & 50 \\
\hline
\end{tabular}

TABLE 3.-EFfect of Adding to the SAme or Different Hemophilic Plasmas Platelets from Two Different Cases of Hemophilia*

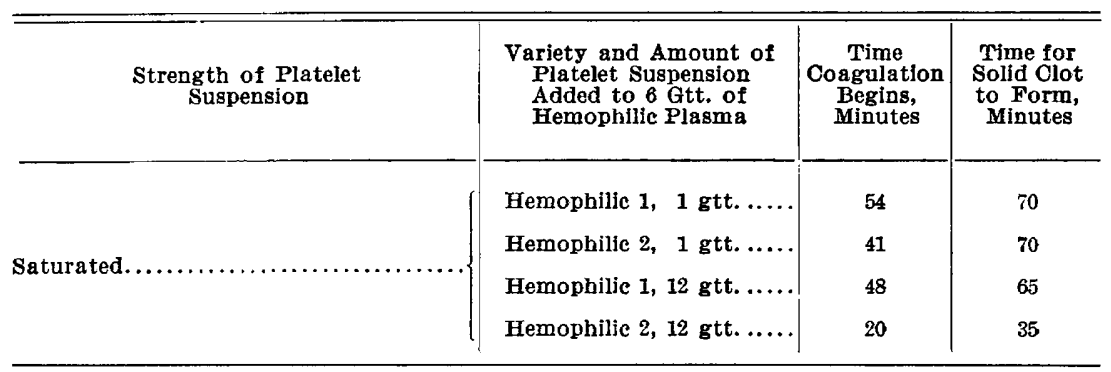

* No. 1 had a shorter coagulation time than No. 2. 
Usually, as shown in Table 1, the normal platelets allowed the hemophilic plasma to clot as rapidly as normal blood; occasionally the normal platelets did not shorten the time of a particular plasma quite so much (Table 2). This may have been due to a poor suspension of normal platelets, since it is possible that in collecting them some of their activity was destroyed. However, a heavy solution of cephalin (Howell's thromboplastic substance ${ }^{10}$ ) added to the hemophilic plasma acted similarly to the normal platelet suspension; that is, if the normal platelets in concentration could shorten the coagulation time of the hemophilic plasma only to twelve minutes, then cephalin could shorten it only to ten or twelve minutes; while if the normal platelet suspension shortened the coagulation time to four minutes, cephalic shortened it to three or four minutes. Such differences seem to have been due to differences in the plasma on the different days. It is possible that the difference was due to some slight alterations in the technic in collecting the blood which were not appreciated. A reasonable interpretation of this difference is the presence of some antagonistic substance in the plasma itself. This substance may be constantly present, but may have been detected only under favorable circumstances. It seems somewhat distinct from the platelets, but may be derived from them.

ACTION OF PLATELETS ON RECALCIFIED OXALATED PLASMA

The Effect of Adding Platelets to Hemophilic Recalcified Oxalated Plasma.-Table 4 shows the results obtained on adding normal and hemophilic platelets to hemophilic oxalated plasma and then adding varying amounts of calcium. This table shows that the normal platelets, even in small amounts, are able to accelerate the clotting time of recalcified oxalated hemophilic plasma more than hemophilic platelets, even when the latter are added in great concentration. This difference between the action of the hemophilic and normal platelets is quite similar to their different action seen when they were added to the unoxalated hemophilic plasma. It is to be noted that if one uses an optimum amount of calcium to recalcify the hemophilic oxalated plasma the difference between adding normal and hemophilic platelets is not so great as when the amount of calcium used is below the optimum. Also it is to be noted that the time of beginning coagulation in the presence of the hemophilic platelets may be nearly the same as in the presence of normal platelets when the optimum amount of calcium is used. However, the time from the appearance of the first fibrin strands to the point at which the clot is solid, is shorter when normal rather than when hemophilic platelets are added. The most striking results are seen when but little calcium is added. In such instances, when one adds one quarter as many normal as hemophilic platelets, a solid clot is formed some minutes before any coagulation is evident in the tube 
containing four times as many hemophilic platelets, which never becomes solid. We interpret these results as follows: Under the most favorable conditions the hemophilic platelets act fairly well, but not so well as normal platelets. Under unfavorable conditions the hemophilic platelets act poorly and some of them probably not at all, so that not enough thrombin is formed or rendered available to complete coagulation.

TABlE 4.-Effect of Normal and Hemophilic Platelets on the Clotting Time of Recalcified Hemophilic Oxalated Plasma

\begin{tabular}{|c|c|c|c|c|c|c|c|}
\hline \multirow[b]{2}{*}{$\begin{array}{l}\text { Strength of } \\
\text { Platelet } \\
\text { Suspension } \\
\text { Added }\end{array}$} & \multirow{2}{*}{$\begin{array}{l}\text { Variety and } \\
\text { Amount of } \\
\text { Platelet } \\
\text { Suspension } \\
\text { Added to } \\
6 \text { Gtt. of } \\
\text { Hemophilic } \\
\text { Oxalated } \\
\text { Plasma }\end{array}$} & \multicolumn{2}{|c|}{$4 \mathrm{Gtt}_{.}, 5 \% \mathrm{CaCl}_{2}$} & \multicolumn{2}{|c|}{$3 \mathrm{Gtt} ., 5 \% \mathrm{CaCl}_{2}$} & \multicolumn{2}{|c|}{$2 \mathrm{Gtt} ., 5 \% \mathrm{CaCl}_{2}$} \\
\hline & & $\begin{array}{c}\text { Coagu- } \\
\text { lation } \\
\text { Begins, } \\
\text { Min. }\end{array}$ & $\begin{array}{c}\text { Time } \\
\text { for } \\
\text { Solid } \\
\text { Clot } \\
\text { to } \\
\text { Form, } \\
\text { Min. }\end{array}$ & $\begin{array}{l}\text { Coagu- } \\
\text { lation } \\
\text { Begins, } \\
\text { Min. }\end{array}$ & $\begin{array}{l}\text { Time } \\
\text { for } \\
\text { Solid } \\
\text { Clot } \\
\text { to } \\
\text { Form, } \\
\text { Min. }\end{array}$ & $\begin{array}{c}\text { Coagu- } \\
\text { lation } \\
\text { Begins, } \\
\text { Min. }\end{array}$ & $\begin{array}{c}\text { Time } \\
\text { for } \\
\text { Solld } \\
\text { Clot } \\
\text { to } \\
\text { Form, } \\
\text { Min. }\end{array}$ \\
\hline \multirow[t]{4}{*}{$\begin{array}{l}\text { About four times as } \\
\text { concentrated as } \\
\text { in blood }\end{array}$} & Normal 2 gtt. & 7 & 10 & 18 & 25 & $\begin{array}{l}\text { Sliding } \\
\text { jelly } \\
\text { clot, } 30\end{array}$ & $\begin{array}{l}\text { Not in } \\
\text { three } \\
\text { hours }\end{array}$ \\
\hline & Normal $5 \mathrm{gtt}$. & 6 & 9 & 10 & 16 & $\begin{array}{l}\text { Sliding } \\
\text { jelly } \\
\text { clot, } 25\end{array}$ & $\begin{array}{l}\text { Not in } \\
\text { three } \\
\text { hours }\end{array}$ \\
\hline & $\begin{array}{l}\text { Hemophilic } \\
2 \text { gtt. }\end{array}$ & 8 & 16 & 30 & Never & Never & $\begin{array}{l}\text { Not in } \\
3 \text { hours }\end{array}$ \\
\hline & $\begin{array}{l}\text { Hemophilic } \\
5 \text { gtt. }\end{array}$ & 8 & 15 & 17 & $\begin{array}{c}36 \text { (never } \\
\text { firm) }\end{array}$ & Never & $\begin{array}{l}\text { Not in } \\
3 \text { hours }\end{array}$ \\
\hline \multirow[t]{4}{*}{ Saturated... } & Normal 2 gtt. & 4 & 7 & 5 & 7 & 7 & 11 \\
\hline & $\begin{array}{l}\text { Hemophilic } \\
2 \mathrm{gtt} .\end{array}$ & 8 & 15 & 14 & \begin{tabular}{|} 
Sliding \\
jelly clot \\
30, never \\
solid
\end{tabular} & Never & $\begin{array}{l}\text { Not in } \\
\text { three } \\
\text { hours }\end{array}$ \\
\hline & $\begin{array}{l}\text { Hemophilic } \\
4 \mathrm{gtt} .\end{array}$ & 8 & 15 & 14 & $\begin{array}{c}\text { Sliding } \\
\text { jelly clot } \\
30, \text { never } \\
\text { solid }\end{array}$ & $\underset{25}{\operatorname{Ting}}$ & $\begin{array}{l}\text { Not in } \\
\text { three } \\
\text { hours }\end{array}$ \\
\hline & $\begin{array}{l}\text { Hemophilis } \\
8 \mathrm{gtt} .\end{array}$ & 7 & 14 & 13 & $\begin{array}{c}24, \text { never } \\
\text { as solid } \\
\text { as with } \\
\text { normal } \\
\text { platelets }\end{array}$ & $\begin{array}{l}\text { Weak } \\
\text { sliding } \\
\text { jelly, } 19\end{array}$ & $\begin{array}{l}\text { Not in } \\
\text { three } \\
\text { hours }\end{array}$ \\
\hline 0 & 0 & $?$ & 60 & $?$ & Never & $?$ & $\begin{array}{l}\text { Not in } \\
3 \text { hours }\end{array}$ \\
\hline
\end{tabular}

The Effect of Adding Platelets to Normal Oxalated Plasma.Table 5 is similar to Table 4 and shows the effect of adding normal and hemophilic platelets to oxalated normal plasma, which is then recalcified. The difference between the action of the hemophilic and normal platelets on recalcified normal plasma is much more difficult to demonstrate than on hemophilic plasma, even using an amount of calcium below the optimum. Better results were obtained with a plasma that had stood forty-eight hours than with plasma a few hours old. With an optimum amount of calcium no especial difference could be 
seen between the accelerating action of normal and hemophilic platelets. With an amount of calcium just below the optimum often there occurred no essential difference in the time that the clots formed in the presence of the two kinds of platelets. In general, the clotting time seemed a shade longer with hemophilic platelets. However, it was always noticed that the clots formed in the presence of the hemophilic platelets were at the time they were solid, distinctly of a weaker nature than those containing normal platelets. Later they became as firm as those with the normal platelets.

By using a suitable amount of calcium that could only be determined for each oxalated plasma by many trials we got the results given in Table 5, under two drops of calcium, where the difference between adding hemophilic and normal platelets is clearly demonstrated. Here, though coagulation at times began at about the same

Table 5.-Effect of Normal and Hemophilic Platelets on the Clotting Time of Recalcified Normal Oxalated Plasma

\begin{tabular}{|c|c|c|c|c|}
\hline \multirow{2}{*}{$\begin{array}{l}\text { Strength of Platelet } \\
\text { Suspension }\end{array}$} & \multirow{2}{*}{$\begin{array}{l}\text { Variety and Amount of } \\
\text { Platelet Suspension Added } \\
\text { to } 6 \text { Gtt. of Normal } \\
\text { Oxalated Plasma }\end{array}$} & \multicolumn{3}{|c|}{$\begin{array}{l}\text { Time in Minutes for Solid Clot to } \\
\text { Form, with } 5 \% \text { Solution } \mathrm{CaCl}_{2} \text { Added }\end{array}$} \\
\hline & & $4 \mathrm{Gtt}$ & $3 \mathrm{Gtt}$ & $2 \mathrm{Gtt}$. \\
\hline $\begin{array}{l}\text { About four times as con- } \\
\text { centrated as blood }\end{array}$ & 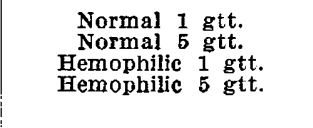 & $\begin{array}{l}4 \\
3+ \\
4+ \\
4\end{array}$ & $\begin{array}{l}7 \\
4- \\
10^{*} \\
4+^{*}\end{array}$ & $\begin{array}{c}9 \\
5+ \\
\text { Never } \\
\text { Beglns 10, } \\
\text { never solid }\end{array}$ \\
\hline Saturated................ & $\begin{array}{l}\text { Normal } 1 \text { gtt. } \\
\text { Hemophilic } 2 \text { gtt. }\end{array}$ & $\frac{4-}{4+*}$ & $\frac{4-}{4+*}$ & $\begin{array}{c}5 \\
6+, \text { never } \\
\text { solid }\end{array}$ \\
\hline 0 & 0 & 8 & $\begin{array}{c}\text { Begins 9, } \\
\text { never solid }\end{array}$ & $\begin{array}{l}\text { Few strands } \\
25, \text { never } \\
\text { solld }\end{array}$ \\
\hline
\end{tabular}

* Though solid at the time given, these clots were not so firm as those containing normal platelets and did not become any flrmer.

time, no matter whether hemophilic or normal platelets were added, the latter allowed a solid clot to form, while the plasma with the hemophilic platelets never became solid. Thus the beginning coagulation time may be near the same time with either kind of platelets, while with hemophilic platelets the ending coagulation time is much delayed.

We assume that only under unfavorable conditions can marked differences be detected between the action of hemophilic and normal platelets on normal plasma. Ordinarily in oxalated normal plasma recalcification makes favorable conditions. As we shall bring out later, our microscopic studies show that hemophilic platelets under favorable conditions undergo transformation not very differently from normal platelets. Irrespective of any possible antagonistic substance in the hemophilic plasma, it is very different from normal oxalated plasma. Hemophilic plasma may well be compared to an oxalated normal 
plasma collected by the most careful technic, as described previously by us. ${ }^{17}$ Such a plasma, in which the greatest care is exercised to prevent any of the changes incident to coagulation, will clot on recalcification with the optimum amount of calcium in forty minutes or more. Under the usual conditions of technic of preparing an oxalated plasma, the plasma will clot upon recalcification in fourteen minutes or less. Under the latter conditions the earlier changes incident to the process of coagulation have already begun and the plasma may be said to be partially prepared for clotting before recalcification. Hemophilic plasma can be readily obtained relatively free from these preliminary changes. On the other hand, normal plasma can be so obtained only by the exercise of special precautions. We have already shown elsewhere that these precautions in normal plasma result in the preservation of intact platelets. In hemophilic plasma the platelets, seemingly fixed, require no such elaborate precautions.

ABILITY OF HEMOPHILIC PLATELETS TO FORM THROMBIN ACCORDING TO THE THEORY OF BORDET AND DELANGE

In order further to determine the difference between hemophilic and normal platelets the ability of each to form thrombin was tested. This was done according to Bordet and Delange's ${ }^{18}$ method. They believe that thrombin is formed by the reaction between cytozyme (platelets and other tissue juices) and serozyme (similar to prothrombin) in the presence of soluble calcium salt. Serozyme is the defibrinated serum obtained after a very clear oxalated plasma, free as possible from platelets, has been clotted by recalcification and kept for twenty-four hours to get rid of any active thrombin. Such a thrombin requires about six or seven minutes to form. The addition of oxalate to a mixture of platelets and serozyme and calcium not only precipitates the calcium and prevents the further formation of thrombin, but also has a deterrent effect on the thrombin. ${ }^{17}$ It is thus possible to demonstrate the amount and activity of a thrombin thus formed within any given time and furthermore to determine the rapidity with which thrombin is formed, since thrombin and fibrinogen react quantitatively to a certain degree, especially if dealing with minute amounts of thrombin.

Table 6 is a typical protocol of often-repeated experiments. For these experiments serozyme, thrombin-free plateiets, calcium solution, and a fibrinogen solution were used. The serozyme was demonstrated to be free of active thrombin in that it did not clot the fibrinogen solution in twenty-four hours. The action of normal and hemophilic

18. Bordet and Delange: Ann. de l'Inst Pasteur, 1912, xxvi, 657 and 737. Lee and Vincent: Footnote 17. 
serozyme was the same. In the tests, to one drop of serozyme was added 0.5 c.c. of a 1 to 100 aqueous solution of calcium chlorid and then suspensions of platelets. The platelets were used in amounts over ten times the minimum required to form enough thrombin to clot the fibrinogen solution in three minutes. After the calcium, serozyme, and platelets had been in contact either six or eight minutes, varying amounts of a 1 per cent. solution of sodium oxalate were added to inhibit the action of forming more thrombin and to paralyze what thrombin had been formed. Then, either immediately or after an interval not exceeding four minutes a fibrinogen solution was added and the time a clot formed was noted. If there was an excess of thrombin formed, the effect of adding a small amount of oxalate did not alter the coagulation time with the fibrinogen solution. If a small amount of thrombin was formed, it paralyzed this small amount and delayed the reaction between thrombin and fibrinogen.

TABLE 6.-Ability of Normal or Hemophilic Platelets to Form Thrombin According to Bordet and Delange's Method*

\begin{tabular}{|c|c|c|}
\hline $\begin{array}{c}\text { Drops of Saturated } \\
\text { Suspension of } \\
\text { Platelets }\end{array}$ & $\begin{array}{l}\text { Amount of } 1 \% \\
\text { Solution of Sodium } \\
\text { Oxalate Added, Gtt. }\end{array}$ & $\begin{array}{c}\text { Clotting Time, } \\
\text { Minutes }\end{array}$ \\
\hline Normal $1 / 4$ or $1 \ldots \ldots \ldots$ & 0 & 3 \\
\hline Hemophille $1 / 4$ or $1 \ldots \ldots \ldots \ldots \ldots \ldots \ldots \ldots \ldots \ldots \ldots \ldots \ldots \ldots$ & 0 & 3 \\
\hline Normal $1 . . . . .$. & $1 / 2$ & 3 \\
\hline Hemophilic $1 . . .$. & $1 / 2$ & 16 \\
\hline 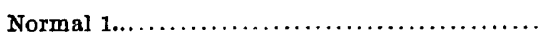 & 1 & 5 \\
\hline Hemophilic $1 . . . . . .$. & 1 & 32 \\
\hline Normal $1 \ldots . . . .$. & 2 & 25 \\
\hline Hemophilic $1 \ldots$. & 2 & About $41 / 2$ hours \\
\hline
\end{tabular}

* In each of the preparations there was 1 gtt. of serozyme and 0.5 c.c. of dilute (1 to 100 ) calcium chlorid solution, to which was added the amount of platelets indicated; then after an interval of six or eight minutes in each instance there was added the amount of oxalate solution given, then either immediately or after waiting not more than four minutes more $6 \mathrm{gtt}$. of a flbrinogen solution was added; clots forming in the time given.

By referring to Table 6 it is seen that a sufficient amount of hemophilic platelets can form enough thrombin to clot fibrinogen in the same time as thrombin formed by normal platelets, provided adequate time was given for the formation of thrombin. However, it is seen that by the addition of oxalate after thrombin has been formed, it takes a much longer time for the thrombin formed by the hemophilic platelets than by the normal platelets to clot the fibrinogen, even in some instances eighteen times as long. This is best explained by the fact that there is a slow formation of thrombin by the hemophilic platelets and that in the given time they have formed less thrombin. That 
there is plenty of thrombin eventually formed has often been shown, since hemophilic serum contains fully as much thrombin as normal. We assume therefore that thrombin is formed more slowly.

To demonstrate further that these hemophilic platelets were slow thrombin formers we used varying dilutions of hemophilic and normal platelet suspensions. It was found that a thrombin formed with one drop of a very weak suspension of hemophilic platelets required a much longer time to clot fibrinogen than when an equal suspension of normal platelets was used. Similar results were obtained with weak, but more concentrated, suspensions. In such an experiment we deal with the great difficulty of making equal platelet suspensions and being able to say they are truly equal. Since the hemophilic blood contained more platelets and yielded platelets more easily, the error favored the hemophilic rather than the normal suspension. However, whether one

TABle 7.-Difference Between Adding Hemophilic Platelet Extract and Suspension to Hemophilic Plasma

\begin{tabular}{c|c|cc|c|c}
\hline $\begin{array}{c}\text { Amount of } \\
\text { Hemophilic } \\
\text { Plasma }\end{array}$ & $\begin{array}{c}\text { Character of Suspension } \\
\text { or Extract of } \\
\text { Hemophilic Plates }\end{array}$ & $\begin{array}{c}\text { Amount of } \\
\text { Extract or } \\
\text { Suspension } \\
\text { Added, } \\
\text { Gtt. }\end{array}$ & $\begin{array}{c}\text { Coagula. } \\
\text { tion } \\
\text { Begins, } \\
\text { Min. }\end{array}$ & $\begin{array}{c}\text { Coagula- } \\
\text { tion } \\
\text { Inter- } \\
\text { mediate, } \\
\text { Min. }\end{array}$ & $\begin{array}{c}\text { Coagula- } \\
\text { tion } \\
\text { Ends, } \\
\text { Min. }\end{array}$ \\
\hline $6 \mathrm{gtt.}$ & 0 & 0 & 360 & $?$ & $?$ \\
$6 \mathrm{gtt}$. & $\begin{array}{c}1 \text { gtt. of saturated suspen- } \\
\text { slon and 5 gtt. of salt } \\
\text { solution }\end{array}$ & 6 & 50 & 80 & 150 \\
$\begin{array}{c}1 \text { gtt. of extract of same } \\
\text { saturated suspension } \\
\text { The same with 9 gtt. of } \\
\text { water }\end{array}$ & 3 & 12 & 10 & 20 & 30 \\
\hline
\end{tabular}

uses a few platelets to form thrombin, or allows a large number of platelets to form what thrombin they can and then this is paralyzed by oxalate, one arrives, of course, at the same results. The actual experimental results are the same and show that the hemophilic platelets act much more slowly in forming thrombin than normal platelets.

In these experiments the fibrinogen solution used consisted of one part oxalated plasma, eight parts 0.9 per cent. salt solution and 0.5 part of 1 per cent. sodium oxalate in 0.9 per cent. sodium chlorid. Both hemophilic and nornial oxalated plasma were used. If hemophilic fibrinogen solution was used to clot the thrombin formed by the interaction of serozyme, calcium and cytozyme, the clots required a slightly longer time to form than if normal fibrinogen was used. This was probably due to the fact that the normal plasma contained a few platelets which acted to accelerate the reaction more than the very few hemophilic platelets in their plasma. 


\section{STUDIES ON THE WHOLE BLOOD}

Addition of Platelets to Whole Blood.--Blood was drawn from the arm vein of a hemophilic patient and 1 c.c. put in each of a series of tubes. One c.c. of this blood coagulated in fifty-five minutes. The addition of one drop of a weak suspension of fresh normal platelets caused this blood to clot in fifteen minutes, while two drops of a correspondingly weak suspension of hemophilic platelets caused the blood

TABle 8.-Coagulation Times of Whole Blood, the Prothrombin Time, and Antithrombin Factor; the Effect of Transfusion oN the Coagulation Time

\begin{tabular}{|c|c|c|c|c|c|}
\hline Date & $\begin{array}{c}\text { Coagula- } \\
\text { tion } \\
\text { Time, } \\
\text { Min. }\end{array}$ & $\begin{array}{l}\text { Pro- } \\
\text { thrombin } \\
\text { Time, } \\
\text { Min. }\end{array}$ & $\begin{array}{c}\text { Pro- } \\
\text { thrombin } \\
\text { Control, } \\
\text { Min. }\end{array}$ & $\begin{array}{l}\text { Anti- } \\
\text { thrombin } \\
\text { Factor }\end{array}$ & Remarks \\
\hline Case 1 & & & & & \\
\hline $\operatorname{March} 10 \ldots \ldots \ldots \ldots \ldots$ & 55 & $\cdots$ & $\cdots$ & $\cdots$ & \\
\hline March $13 \ldots \ldots \ldots \ldots \ldots$ & 70 & 50 & 10 & $1+$ & No bleeding or \\
\hline March $19 . \ldots \ldots \ldots \ldots \ldots$ & 40 & 28 & 8 & 1.5 & $\begin{array}{l}\text { tient's condi- } \\
\text { tion }\end{array}$ \\
\hline Mareh $23 \ldots \ldots \ldots \ldots \ldots$ & 70 & 50 & 8 & 1.35 & \\
\hline March $26 \ldots \ldots \ldots \ldots \ldots$ & 50 & 45 & 10 & 1.2 & \\
\hline $\begin{array}{c}\text { Case } 2 \\
\text { March } 19 \ldots \ldots \ldots \ldots\end{array}$ & 100 & 70 & 8 & 1.35 & \\
\hline March $21 \ldots \ldots \ldots \ldots \ldots$ & 60 & 49 & 12 & 1.3 & $\begin{array}{l}\text { No change in } \\
\text { patient's con. }\end{array}$ \\
\hline $\operatorname{March} 23 \ldots \ldots \ldots \ldots \ldots$ & 82 & 60 & 10 & 1.15 & $\begin{array}{l}\text { dition or bleed- } \\
\text { ing }\end{array}$ \\
\hline $\begin{array}{l}\text { March } 31 \text { (before trans- } \\
\text { fusion) }\end{array}$ & 150 & 85 & 12 & $\cdots \cdots$ & \\
\hline $\begin{array}{l}\text { March } 31 \text { (after trans. } \\
\text { fusion) }\end{array}$ & 8 & . & . & $\cdots \cdots$ & $\begin{array}{l}\text { March } 81 \text { trans- } \\
\text { fused } 600 \text { c.c. }\end{array}$ \\
\hline $\begin{array}{l}\text { March } 31 \text { (6 hours after } \\
\text { transfusion) }\end{array}$ & 10 & . & $\cdots$ & $\cdots \cdots$ & $\begin{array}{l}\text { of blood from } \\
\text { donor, whose } \\
\text { coagulation } \\
\text { time was } 7\end{array}$ \\
\hline April $1 \ldots \ldots \ldots \ldots \ldots$ & 17 & $\cdots$ & $\cdots$ & $\cdots \cdots$ & \\
\hline April $2 \ldots \ldots \ldots \ldots \ldots \ldots$ & 25 & $\cdots$ & . & $\cdots \cdots$ & \\
\hline April $3 \ldots \ldots \ldots \ldots \ldots$ & 60 & . & . & $\cdots \cdots$ & $\begin{array}{l}\text { April } 7 \text { sponta- } \\
\text { neous hemor- }\end{array}$ \\
\hline April $5 \ldots \ldots \ldots \ldots \ldots$ & 100 & $\cdots$ & $\cdots$ & $\cdots \cdots$ & $\begin{array}{l}\text { rhage into } \\
\text { right knee }\end{array}$ \\
\hline April $12 \ldots \ldots \ldots \ldots \ldots$ & 55 & $\cdots$ & $\cdots$ & $\cdots \cdots$ & joint \\
\hline April $14 \ldots \ldots \ldots \ldots \ldots \ldots$ & 115 & $\cdots$ & $\cdots$ & $\cdots \cdots$ & \\
\hline April $20 \ldots \ldots \ldots \ldots \ldots$ & 100 & $\cdots$ & $\cdots$ & $\cdots \cdots$ & \\
\hline
\end{tabular}

to coagulate in forty minutes. One drop of a "saturated" suspension of normal platelets caused coagulation in five minutes and double this amount of hemophilic platelets caused coagulation in twenty-five minutes. The first fibrin strands in the tubes containing the hemophilic platelets appeared from one to four minutes after they appeared in those with the normal platelets, but coagulation proceeded to completion much more slowly. It is important in order to get these wide differences to use fresh preparations of platelets. We have found that 
the hemophilic platelets on standing for over twenty-four hours seem to undergo some change, since in some instances these old hemophilic platelets acted more rapidly than the freshly prepared platelets. The results with hemophilic and normal bloods were consistent with those obtained with the hemophilic plasma, oxalated hemophilic, and normal blood plasma.

Studies on the Coagulation Time of the Whole Blood.-The coagulation time of the whole blood was determined by the method of Lee and White, ${ }^{19}$ which is to allow 1 c.c. of blood drawn from a vein to clot firmly in a tube eight $\mathrm{mm}$. in diameter. By this procedure normal blood clots in five to ten minutes. The results are seen in Table 8 , and show the usual prolongation of the coagulation time of hemophilic blood. Fluctuations occurred without evident reason, such as has been noted by others.

CASE 1.-A man, 50 years of age, and the man in Case 2, who was 25 years of age, both gave a clean cut family history of hemophilia and had suffered from nose bleeds and severe bleeding from injuries. One gave a history of hematuria. Both had suffered since childhood with repeated attacks of swelling, stiffness and pain in the various joints of the body and the joints gave the typical appearance of chronic hemophilic joints. In Case 1 there had been no acute joint swelling or pain for three months before entrance, but the patient had had some bleeding from his gums six weeks previously, associated with carious teeth. In Case 2 there was an acute swelling of the knee some two months before entrance, but the patient had had no other hemorrhagic symptoms for over a year. During his stay in the hospital he developed again acute swelling and pain in his knee, subsiding after ten days. Otherwise during the present study of these cases there was no evidence of bleeding.

CASE 2 is of especial interest. In view of the fact that normal platelets in small amounts in vitro could shorten the hemophilic coagulation time, it was thought that the transfusion of normal blood might shorten the coagulation time of the hemophilic blood, and that the lasting effect of such a procedure would be evident as long as the life of the normal transfused platelets. To test this point, with the enthusiastic approval of the patient Dr. Vincent transfused the second patient with 600 c.c. of blood from a donor of the same iso-agglutination group, whose coagulation time was seven minutes and whose platelets were normal in numbers. Before the transfusion 500 c.c. of blood were removed from the patient. Allowing that the patient's and donor's blood volume was 5 liters, the number of normal platelets that were given this patient would be about 24,000 per c.c.

The coagulation time one and one-half hours before transfusion was 150 minutes. On this same day directly before transfusion the coagulation time determined by obtaining blood through a paraffined cannula and allowing it to run directly into the glass coagulation time tube was four and one-half hours. It was quite striking to find directly after the transfusion that the hemophilic blood clotted in normal time, as it also did six hours after transfusion. There was a definite gradual lengthening of the coagulation time, so that it was sixty minutes three days, and 100 minutes five days, after the transfusion.

Thus the effect of the transfusion was not evident after three days. This time coincides with our ideas of the life of the platelets, as pointed

19. Lee and White: Am. Jour. Med. Sc., 1913, cxlv, 495. 
out by Duke. ${ }^{20}$ It seems reasonable to suppose that the effect of the transfusion was due to the normal platelets, that as they began to "die" the coagulation time lengthened and kept on doing so until its previous delayed time was reached, at which time all the normal platelets had died off.

Character of the Blood Clot.-The clots of the whole blood always retracted fully as much as normal clots and gave the typical appearance of hemophilic clots, that is, white on top, red below, with greater retraction at the top of the clot because of the richness of the platelets in this region. Clots from clear plasma did not retract unless a sufficient amount of platelets had been added; these clots never seemed to retract as well as blood or cloudy plasma, containing numerous platelets which had not been first removed.

If after the hemophilic blood had apparently clotted firmly the clot was loosened and removed from the fluid, the fluid would clot and would do so sometimes almost at once, often in three to five minutes and sometimes not for ten to thirty minutes or more. Again on separating the clot, but not removing it from the serum, this reclotting phenomenon occurred and might be repeated from three to six times. The reclotting would occur no matter whether the clot was loosened a few minutes or a few hours after it had appeared solid. If one waited hours rather than minutes after the clot had formed, one usually obtained the reclotting phenomenon fewer times. This same phenomenon was observed on clotting hemophilic oxalated plasma with calcium to obtain serozyme. (It was first called to our attention by Dr. Howell.) This phenomenon has been observed in a number of cases of hemophilia and in other cases with delayed coagulation time and prolonged prothrombin time. Of some twenty-five observations on eight cases which have exhibited this phenomenon, none have shown an antithrombin content below one, ${ }^{21}$ while almost all the observations have shown an increase in antithrombin. It was thought, as suggested by Dr. Howell, that the increased antithrombin content had something to do with this phenomenon. This phenomenon is also seen in preparing serozyme from very clear normal oxalated plasma. An explanation which now occurs to us is that the phenomenon is associated with a slow formation of thrombin. Thrombin may be slowly formed from at least two causes traceable to blood platelets. In the case of hemophilia the blood platelets, while sufficiently numerous, are not readily available for purposes of coagulation, hence a slow formation of an ample amount of thrombin. In the case of purpura hemorrhagica associated with a low blood platelet count we may have a slow formation due to the paucity of blood platelets. Under normal conditions

20. Duke: Jour. Exper. Med., 1911, xiv, 265.

21. Minot, Denny and Davis: The Archives Int. Med., 1916, xvii, 101. 
there is probably an excess of blood platelets, and as several observers have elsewhere shown, the excess of blood platelets over the number actually required for coagulation acts in retracting the clot. In purpura hemorrhagica there is no clot retraction, since all the blood platelets are used for thrombin formation, which is relatively slow due to the necessity of using all the blood platelets.

FURTHER STUDIES ON PLATELETS

In these two cases of hemophilia the platelet count determined by Wright and Kinnicutt's ${ }^{22}$ method was from 290,000 to 400,000 , that is at or slightly above the upper limit of normal.

The Bleeding Time.--The time a patient bleeds from a puncture in the ear has been shown by $D_{u k e^{23}}$ to be prolonged in conditions with very few platelets. In such conditions, however, the coagulation time is often normal, although it may be somewhat delayed. It seems that in such cases there is enough thrombin to allow the blood to clot in normal time, or not greatly beyond the normal time, though in our experience a weak clot occurs. One must realize that it probably takes very few normal platelets to do their share in allowing blood to coagulate in normal time and that a little thrombin can cause fibrinogen to clot, though weakly, in the same time as much larger amounts; while with minimal amounts of thrombin the time is delayed and the clot is weak. Duke tested the bleeding time of but one case of hemophilia and found it normal. Other observations have recently been made by Hess, ${ }^{7}$ who found this time normal in several hemophilic cases, which is in accord with our repeated findings in these two cases and also in three others of typical hemophilia. The bleeding time from an arm vein was also normal in these cases. It is rather surprising that typical cases of hemophilia, in which bleeding occurs readily after cuts, injuries, etc., and which show a marked delay in the coagulation time of the blood, do not always have an abnormal bleeding time. Whether this is to be considered entirely due to the fact that their platelets are plentiful in numbers will be referred to later.

Studies on the Metamorphosis of the Platelets.-Under the microscope we have repeatedly observed the agglutination and fusion into glassy-like masses and often dissolution of the platelets that occurs when any serum containing active thrombin and calcium is allowed to act on platelets. The action of antithrombin, oxalated plasma, pure thrombin, etc., and combinations of such blood elements on blood platelets is reserved for a future communication. We were, however, unable to detect that hemophilic or normal serum, antithrombin, serozyme, plasma, pure thrombin and calcium and various combinations of

22. Wright and Kinnicutt: Jour. Am. Med. Assn., 1911, lvi, 1457.

23. Duke: The Archives Int. Med., 1912, x, 445. 
such substances acted differently on hemophilic than on normal platelets. No matter whether the platelets were washed one or more times or whether they were obtained from oxalated plasma or magnesium sulphate plasma. Whatever permitted the metamorphosis of the hemophilic or normal platelets did so as readily and quickly with hemophilic as with normal coagulation elements. Dr. J. Homer Wright could find no particular histologic difference in the fused masses of hemophilic and normal platelets, whether caused by hemophilic or normal serum acting on the platelets for a longer or shorter period.

It is noteworthy that no fusion or microscopic change occurred in the platelets in the hemophilic plasma or blood until fibrin strands began to form from thirty to forty minutes after withdrawing the blood, which clotted firmly in seventy minutes. Practically all the platelets were more or less fused, some more than others, five to eight minutes after the process began.

The platelets from the depth of the red cell sediment obtained after centrifugalizing twenty minutes the whole blood and after the plasma was removed appeared clumped, but not fused. After some hours these platelets appeared the same, though the plasma had clotted. After twenty-four hours they appeared disintegrated, rather than fused, and the red cell sediment showed no clot.

It has often been suggested that the platelets are important factors in the coagulation of the blood and that they have something to do with the initial stage of coagulation. In most theories it is agreed that immediately as blood is shed it undergoes some change which makes it quite different from normal circulating blood and enables coagulation to ensue. The duration of this stage is probably short, but concerning it very little is known. It is perhaps significant that with the first visible signs of coagulation the platelets begin to undergo this metamorphosis. Perhaps before coagulation and metamorphosis of the platelets can properly proceed, certain substances in the platelets must go into solution. Such substances derived from the platelets probably occur in solution in the circulating blood.

\section{ULTIMATE FATE OF THE BLOOD PLATELETS}

It has been shown by Wright ${ }^{24}$ that the platelets are formed from the megakaryocytes of the bone marrow and spleen. Their life is short, probably a few days, as shown by Duke and as suggested by the results of transfusion in our hemophilic patient. The ultimate destiny of the blood platelets has not been studied. We have no knowledge on this point. There must be a constant destruction. A possible explanation is that after their disappearance as fixed elements in the blood the active principle presumably is taken up by the tissues and is present in

24. Wright: Jour. Morphology, 1910, xxi, 263. 
tissue juice and known as the thromboplastic substance of the fixed tissues. The active coagulating principle of tissue juice accelerates coagulation in a similar fashion as do the blood platelets. If this theory is correct and if we may assume that the difficulty with hemophilic platelets is that they cannot go into solution or start to make thrombin as readily as normal platelets, one ought to be able to show two things: first, that hemophilic tissue juice acts as efficiently as normal; secondly, that hemophilic platelets in solution are more effective than in suspension, that is, in solution their action is like normal platelets in suspension.

Sahli ${ }^{9}$ and Morawitz and Lossen ${ }^{8}$ have believed that the hemophilic tissue juice was lacking in thromboplastic activity, but they have given no experimental proof. Gressot ${ }^{25}$ is the only one who has studied the thromboplastic action of hemophilic tissue. He showed from a study of hemophilic organs obtained at necropsy that the tissue juice of hemophiliacs is as active as normal. One of us had the opportunity one and one-half years ago to study the thromboplastic activity of hemophilic tissues obtained from a patient with typical hemophilia, who died after having transfusion performed. We found, as did Gressot, that we could not detect any ineffectiveness of the hemophilic tissue to accelerate the coagulation of normal blood or normal recalcified oxalated plasma, but its action on hemophilic blood or plasma was not tested. However, the hemophilic tissue acted in no wise differently from normal tissue juice.

On the theory that platelets on being destroyed go into solution and this substance in solution is what is known as tissue juice we might explain the reason for a normal bleeding time in hemophilia in the following manner: Once that the resistant hemophilic platelets go into solution we have an essentially normal tissue juice. It is the tissue juice that is the important element that affects the bleeding time, rather than the number of platelets. The thromboplastic substance appears to be normal in hemophilic tissue and perhaps when a small puncture is made in the ear to test the bleeding time enough of the tissue juice exudes to allow the blood to clot rapidly. If the wound is large so that loss of blood is comparatively rapid and great, we can conceive that enough tissue juice is not available to check such a hemorrhage occurring with a blood with such an abnormal coagulation time. We have occasionally observed that with a grossly faulty technic of vein puncture which allowed a liberal addition of tissue juice, that the hemophilic blood clotted in time approaching that of normal blood and that the hemophilic plasma from such a blood approached normal plasma in its behavior. On the contrary, in cases of purpura hemorrhagica with a diminished number of platelets and

25. Gressot: Footnote 1, third reference. 
an abnormally long bleeding time, it is possible to explain the long bleeding time by supposing that it is due to a deficiency of the tissue juice, which in turn is conceivably dependent on a constant replenishment from the solution of the platelets in the tissues, rather than that the bleeding time is entirely dependent on the number of platelets. On such a hypothesis the few platelets would be the cause of the diminished amount of tissue juice and this diminished quantity of active tissue juice would be more directly the cause of the prolonged bleeding time than the few platelets per se.

We have no evidence that tissue juice of cases of purpura hemorrhagica is or is not normal. The observation of $\mathrm{Minot}^{2 \mathrm{~B}}$ on the thromboplastic activity of the uterus removed at operation in such a case is perhaps at first sight against such a theory. He observed that this tissue had thromboplastic activity. On this patient, however, transfusion had been performed forty-eight hours before and also directly before the operation, which might well have altered the thromboplastic content of the organ. Again, differences of thromboplastic activity might be less capable of demonstration on normal plasma than on hemophilic. This was not done.

In regard to the solution of the platelets, we investigated the relative fragility of hemophilic and normal platelets and the efficacy of so-called platelet solutions in accelerating coagulation as contrasted with platelet suspensions. Attempts were made to test the fragility of normal and hemophilic platelets against varying strengths of salt solution, as one tests the fragility of the red cells. No differences could be detected, macroscopically, in regard to their solution. This was because normal platelets even in distilled water do not break up as do red cells. They swell and change their morphologic character somewhat, but to the naked eye the mass left after standing several hours in either normal salt solution or water appears the same. However, if the supernatant fluid is removed from the platelets which have been in water for some time and compared to salt solution in which platelets have stood, the water solution clearly has more thromboplastic action than the salt. Further studies on the microscopic appearance of the platelets after standing in different strengths of salt solution are desirable.

Hemophilic platelet solutions and suspensions were made numerous times and tested to see if we could find any difference in their cytozymic action. It was found impossible by simply using water to get complete solution, so that our platelet solutions always contained some platelets in suspension. The protocol in Table 7 shows the results obtained several times when hemophilic platelet suspensions and extracts were added to hemophilic clear plasma.

26. Minot: Am. Jour. Med. Sc., 1916, clii, 48. 
In these experiments it did seem as if the hemophilic platelet solution was more efficient than the hemophilic platelet suspension in its ability to clot the hemophilic plasma. If the solution was kept an hour or so before it was used it was sometimes, but not always, more effective than if used directly after it was made up.

One series of experiments was made with extracts and suspensions of normal and hemophilic platelets on accelerating the clotting time of recalcified hemophilic oxalated plasma. Differences between the action of extracts and suspension were very slight. Ofter both acted equally well and such differences as shown when the plasma was studied were not demonstrated.

Attempts were also made to see if extracts of normal and hemophilic platelets were more effective in forming thrombin with serozyme and dilute calcium than suspensions of normal and hemophilic platelets. The results varied. Perhaps more frequently the extracts seemed to be rather better than the suspensions in being able to form thrombin. On the other hand, the reverse result was sometimes obtained. We have at present no satisfactory explanation for the inconsistent results of these experiments.

From the results of our studies on the ability of platelets in solution to act more efficiently than in suspension, it is seen that one set of experiments showed this to be apparently true, while other experiments were inconclusive or negative. It is desirable to study such differences probably by other means, by aid of other substances to cause better solutions, for example, action of minimal doses of roentgen rays, etc. At present one can say that some results are suggestive of differences. This is not entirely in accord with Fonio, ${ }^{27}$ who found solutions of platelets less or equally active with their suspensions.

\section{THE PROTHROMBIN TIME}

The prothrombin time, the time it takes a solid clot to form from oxalated plasma on recalcification with the optimum amount of calcium, was determined by the method described by Howell ${ }^{5}$ and discussed by Minot, ${ }^{28}$ and by Minot, Denny and Davis. ${ }^{21}$ This time was found abnormally long; as may be seen by referring to Table 8 . Such a markedly delayed prothrombin time is characteristic of hemophilic blood, as has been shown by Howell, ${ }^{5}$ Addis, ${ }^{13}$ Hurwitz and Lucas, ${ }^{\circ}$ Minot, Denny and Davis, ${ }^{24}$ and Hess. ${ }^{7}$ There was no evidence that the available calcium was at fault in these hemophilic cases, as evidenced by the fact that the optimum amount of calcium needed to recalcify the plasma from the cases and the controls was the same. The in vitro test

27. Fonio: Footnote 1, first reference.

28. Minot: Jour. Med. Research, 1916, xxxiii, 503. 
of Lee and Vincent ${ }^{29}$ showed that a drop of calcium added to 1 c.c. of blood or plasma did not alter the coagulation time or shortened it but very slightly, not giving the striking changes seen in certain cases of jaundice.

\section{THE ANTITHROMBIN}

The antithrombin was tested for by a modification of Howell's ${ }^{5}$ method and that previously used by Minot, Denny and Davis. ${ }^{21}$ This modified method gives less variation of the antithrombin in normal blood than that previously found by Minot, Denny and Davis. The antithrombin factor or quotient was found to be normal or more usually slightly above normal (Table 8). Such findings have been reported before. It is unfortunate that we were unable to determine the prothrombin time and antithrombin in the second case after transfusion. A heavy suspension of hemophilic platelets was able to neutralize antithrombin from hemophilic serozymes, plasma or serum as rapidly and readily as normal platelets. Dealing with dilute suspensions of platelets, which are notoriously uncertain in regard to their equality, we seemed to find the hemophilic platelets less able to neutralize antithrombin than were normal platelets.

\section{MISCELLANEOUS STUDIES}

The addition of normal or hemophilic active serozyme to whole hemophilic blood or normal or hemophilic recalcified oxalated plasma did not affect the clotting time if the serozyme was free of thrombin.

The addition of an amount of pure thrombin made according to Howell's ${ }^{30}$ methods fully sufficient to clot solidly normal blood or oxalated plasma in two minutes likewise clotted solidly in two minutes hemophilic blood, plasma or oxalated plasma. When an amount of pure thrombin was used that just clotted firmly normal plasma the hemophilic plasma might be clotted a little less firmly. Such differences as this in these cases were very slight. In the study of various cases in the past, though not without exception, such a difference has been concomitant with an increase of antithrombin, as it was in these cases.

The addition of cephalin, or tissue extracts, like normal platelets, clotted hemophilic plasma or blood rapidly.

Hemophilic serum clotted normal or hemophilic plasma equally well and in essentially the same time as did normal serum.

We have tested the hydrogen ion concentration of the blood in these cases by the method described by Levy, Rowntree and Marriott ${ }^{31}$ and found it normal, as did Hurwitz and Lucas. ${ }^{B}$

29. Lee and Vincent: The Archives Int. Med., 1915, xvi, 59.

30. Howell: Am. Jour. Physiol., 1910, xxvi, 453; ibid., 1913, xxxii, 264.

31. Levy, Rowntree and Marriott: The Archives Int. Med., 1915, xvi, 389. 
We have found no evidence in several cases of hemophilia of any fibrinolytic ferment present in the circulating blood during life. This is in accord with Morawitz and Lossen ${ }^{8}$ and the recent findings of Hurwitz and Lucas. ${ }^{6}$

Dr. A. H. Rowe tested the albumin and globulin content of the plasma by T. B. Robertson's methods and found it essentially normal as did Hurwitz and Lucas. ${ }^{\circ}$

In regard to the occurrence of nontypical types of hemophilia, we would like to emphasize that there are various atypical and intermediate types of hemophilia and purpura hemorrhagica; that there is undoubtedly a hereditary type of purpura and that this may occur in a female member of a family, some of whose male members are typical hemophiliacs; that atypical cases giving a history of hemophilia may at certain times have a normal or nearly normal coagulation time; that an antithrombin increase may perhaps at times be more marked than normal in some of these cases; that some cases may appear at one time to be more of a hemophilic nature and at other times more of a purpuric nature; that is, at one time they may show a normal platelet count, but a marked delay of the coagulation time, while at other times the coagulation time may be less delayed, while the blood platelets are very few in numbers.

The fact that cases of purpura hemorrhagica are associated with few platelets, on which the bleeding time depends indirectly or directly, and that cases of intermediate types of purpura and hemophilia exists, suggests again that an alteration in the platelets is the cause of the abnormal coagulation phenomenon of hemophilic blood. We would suggest from our studies that the hemophilic platelets are qualitatively defective in that they cannot start the process of coagulation as well as normal platelets, that as cytozyme they cannot act as rapidly to form thrombin or to accelerate the coagulation of the blood. In Howell's terminology we can interpret our findings to indicate that the hemophilic platelets cannot give up their prothrombin so readily as normal platelets, rather than that they are deficient in their prothrombin content; this would agree with Addis' conception of the cause of the slow coagulation of hemophilic blood. If this is true, one would expect to find a marked diminution compared to normal in the circulating prothrombin in solution, while the total prothrombin (in solution and bound) would occur in normal amounts. Perhaps the much delayed prothrombin time of hemophilic plasma is explained on such a basis, that is, that it contains minimal amounts of free soluble prothrombin or its antecedents. 


\section{SUMMARY AND CONCLUSIONS}

The blood platelets from two typical cases of hemophilia have been studied, because in the course of some work on coagulation we have been greatly impressed by the importance of the blood platelets. Previous work has shown that in typical hemophilia the formed elements are in essentially normal numbers. The calcium and fibrinogen content of the blood and thrombin in the serum are within normal limits. The antithrombin is normal or often slightly increased. The activity of the tissue juice is probably normal. The prothrombin time is markedly delayed. These results agree with the findings in our cases.

The hemophilic blood platelets were obtained directly from the blood and from various types of salted plasmas. If normal blood platelets in about normal amounts were added to hemophilic plasma they caused it to coagulate in a time that is normal or nearly normal. When hemophilic blood platelets were added even in approximately seventy-five times as great a concentration as in normal blood, though they definitely shortened the coagulation time, they never brought that time to anything approaching normal limits.

By using the method of formation of thrombin described by Bordet and Delange, the blood platelets required more time to form thrombin when derived from hemophilic than from normal blood. This is consistent with the reclotting phenomenon observed in hemophilic bloods.

Microscopically, under favorable conditions of thrombin, etc., hemophilic platelets undergo the usual transformation in apparently normal time. Under the most favorable conditions hemophilic platelets act nearly normally. On the other hand, in the case of oxalated plasma, recalcified by an amount of calcium that is not the optimum amount, wide discrepancies are seen in the clotting times when normal and hemophilic platelets are added.

This evidence suggests, as does the fact that partial solution of the hemophilic platelets in water was usually more efficient than hemophilic platelets in suspension, that the delay in coagulation in hemophilia occurs in the initial step in coagulation, which seems to be a rendering of the platelets available by some process like solution.

We are inclined to present the theory that the active coagulating principle of the tissue juice is derived in part, if not wholly, from the blood platelets. As evidence on this point we present the fact that in hemophilia with a normal number of abnormally resistant platelets we have a very abnormal coagulation time, but a normal bleeding time. In purpura hemorrhagica these conditions are just the opposite. The normal number of platelets, though few in number, are sufficient to form a little thrombin and clot fibrinogen in essentially normal time. The value of an excess of platelets seems to be to furnish the active coagulating principle of the tissue juice. 
On one of the hemophilic patients transfusion was performed with 600 c.c. of normal blood. The coagulation time before transfusion was from sixty to 120 minutes. After transfusion it was seven minutes. A gradual lengthening of the coagulation time occurred for three days, when it was again sixty minutes. Since about three days is generally assumed to be the length of life of the blood platelet, our actual clinical findings seem to corroborate the findings in vitro.

We conclude that in hemophilia we have an hereditary defect in the blood platelets. This defect consists of a slow availability of the platelets for the purposes of coagulation.

188 Marlborough Street-Massachusetts General Hospial. 